\title{
Websites for the business of biotechnology
}

\section{Michael Francisco}

For those interested in the business of biotechnology, the Internet is an essential tool for keeping current with company information as well as the financial markets. It is also the great equalizer, accessible to everyone from undergraduates planning their futures and individual investors to big pharma CEOs and Wall Street analysts.

Although the prohibitive costs of subscribing to the proliferation of faxed headline services, industry newsletters and magazines, and even business newspapers are an obstacle to getting timely information for many, the World Wide Web has in some ways leveled the playing field by offering these services for free. Wire services offering up-to-the-minute press releases are available from PR Newswire and BusinessWire; some sites offer online magazines with in-depth features and industry analysis (e.g., ReCap's Signals), and, as evident from a recent barrage of television and print advertising in the US, there is no shortage of financial sites from which you can check your stock prices in real-time and then carry out your own trades.

Previously, tracking information on the Web meant hours of Internet surfing. Most individual companies have their own cor- porate websites, with all the customary features: Backgrounders, press releases, and publications. However, sorting through these is time-consuming. Fortunately, there are now several websites that collect biotechnology company information and news for easy searching. The best of these are BioSpace and ReCap. There are also sites that focus strictly on the financial side of the industry, such as Quote.com, as well as on the science side, such as Biofind. Best of all, the lion's share of content on the Internet is still free, though some sites require registration.

\section{Selected websites for biotechnology industry information}

\section{BioSpace}

http://www.biospace.com

A high-traffic, highly searchable "hub" site updated daily with news, industry events, and career opportunities from over 300 bioscience companies, pharmaceutical companies, lab service providers, contract research organizations, suppliers, and professional service firms.

\section{ReCap}

http://www.recap.com

Bills itself as a biotechnology "industry filing cabinet," providing searchable company news, press releases, clinical trials information, valuation histories, and alliances with analyst reports. There is also a discussion forum, slide presentations from recent conferences, and an online magazine.

\section{Institute for Biotechnology Information}

http://www. biotechinfo.com

Offers strategic business information for the biotechnology and pharmaceutical industries. Subscribers may order publications and gain access to IBI's databases for US companies and venture capital sources.

\section{Quote.com}

\section{http://www.quote.com}

The most comprehensive financial data site on the Internet, with available real-time stock prices, news, earnings forecasts, market analysis, commentary, annual reports, charts, weather information, and company profiles for over 100 industries in the US and Canada. Subscribers can also track company portfolios and receive relevant real-time news and stock price alarm notification by e-mail.

\section{SciWeb}

http://www.sciweb.com/business.html

A collection of SciWeb's own pages and links to other information providers for accessing biotechnology industry data, including stock updates, initial public offerings, merger and acquisition activity, and SEC filings.

\section{Yahoo/Reuters Financial News}

http://biz.yahoo.com

Use Yahoo's business page for simple searches through Reuters' and BusinessWire's comprehensive and up-to-date company press releases. Releases are stored for approximately 1 week due to the database's sheer volume.

\section{Patent Explorer}

http://www.derwent.com/patex/

To find patent information for monitoring trends, tracking infringement, and uncovering licensing opportunities, you can enlist Derwent's Patent Explorer to search US and European patent data and patent application documents. Searches are customizable, and results can be delivered via on-line download, fax, or express or regular mail.

Biofind

http://www.biofind.com

The home of the always busy Biotech Rumor Mill, as well as a listing of biotechnology events, employment opportunities, and an "innovations" database for posting research project outlines with commercial potential in need of venture capital or corporate funding. 